Trinity University

Digital Commons@ Trinity

English Faculty Research

English Department

Spring 2008

\title{
In Defense of Genius: Howells and the Limits of Literary History
}

Claudia Stokes

Trinity University, cstokes@trinity.edu

Follow this and additional works at: https://digitalcommons.trinity.edu/eng_faculty

Part of the English Language and Literature Commons

\section{Repository Citation}

Stokes, C. (2008). In defense of genius: Howells and the limits of literary history. American Literary Realism, 40(3), 189-203. doi: 10.1353/alr.2008.0025

This Article is brought to you for free and open access by the English Department at Digital Commons @ Trinity. It has been accepted for inclusion in English Faculty Research by an authorized administrator of Digital Commons@ Trinity. For more information, please contact jcostanz@trinity.edu. 


\section{CLAUDIA STOKES}

\section{In Defense of Genius: Howells and the Limits of Literary History}

In early 1886 , William Dean Howells fell into an ugly public debate with the poet and critic Edmund Clarence Stedman. Carried out in the pages of Harper's Monthly and the New Princeton Review, this dispute started as a disagreement about the origins of literary craftsmanship but quickly escalated into a heated epistemological squabble about the limits of historical knowledge. It began in March of that year, when Howells gave a mixed review to Stedman's Poets of America (1885), a history of American poetry. Though Howells conceded the importance of Stedman's contribution to the emerging discipline of American literary history, he openly mocked a few of Stedman's claims: his prediction of an American poetry revival and his staunch belief in genius, a category of achievement Stedman used with great liberality. Stedman was humiliated by Howells' published remarks, and he responded six months later with the essay "Genius," in which he feebly attempted to defend the scholarly claims of Poets of America. Though the two long-time friends visibly struggled to remain cordial, their strained politeness occasionally gave way to underhanded barbs: Howells, for example, wryly remarked that genius was merely "the fancy of those who hope that someone else will think they have it." ${ }^{1}$ This uncharacteristically prickly exchange generated so much attention at the time that other periodicalsamong them The Critic, the Boston Gazette, and the Penny Post-published articles about it, providing summaries of each man's arguments while studiously avoiding taking sides. And though the two men soon resumed their friendship and collegial rapport, neither was willing to let the matter go or concede defeat: Howells reprinted much of his 1886 review in Criticism 
and Fiction (1891) and Stedman continued to restate his own positions for the rest of his life. ${ }^{2}$

There is more to this public feud than perhaps meets the eye. Though their squabble about poetry and genius may seem quaint and old-fashioned today, the stakes of this quarrel were high. For the prize each man so fiercely sought was controlling influence over the aesthetics and practices of literary history, a genre that was still so new to the United States that its methods remained unfixed and amenable to influence. ${ }^{3}$ Indeed, Howells' chief objection to Stedman's Poets of America was his transparent use of literary history to consolidate and promote his own generic and aesthetic allegiances. Howells countered not by suggesting that literary history remain unbiased by such obvious literary partisanship but by suggesting that his own literary values-diligence, positivism, and the belief in historical determinacywould serve as better organizing rubrics. As this essay will show, Howells more successfully argued his case and characterized Stedman's methods as slipshod, superstitious, and unsuited to serious scholarship. This 1886 exchange tipped the scales in favor of the methods Howells recommended, and the literary history produced in its aftermath is characterized by a firm confidence in the evidentiary powers of data and the expository, narrative form that Howells endorsed, despite Stedman's skepticism about the intellectual restrictions of both. The Howells-Stedman feud also warrants our attention because it exposes the aesthetic character of these seemingly neutral methodologies, which have been in place for over a century.

Though Stedman has long been forgotten by American readers and literary scholars alike, he was Howells' peer and counterpart in the literary late century. Both men launched their careers as poets in the $1860 \mathrm{os}$, and, though Howells later switched from poetry to narrative fiction, Stedman became the preeminent poet and poetry critic of the era. By the 1870 , just as literary histories started to proliferate amid the centennial celebrations, Stedman began writing literary histories, and Poets of America, his first foray into American literary history, was conceived as an American complement to his highly successful Victorian Poets (1875), a study of nineteenth-century British poets. By the end of the century, Stedman's literary output was limited exclusively to criticism and literary history, as with his work editing numerous literary anthologies such as the Victorian Anthology (1895) and the American Anthology (1900). Howells was similarly interested in literary history, and he kept up with developments in the field by reviewing countless literary histories in his Harper's columns. Like Stedman, his interest led him to try his hand at the genre, as with his Heroines of Fiction (1901), an ambitious two-volume history of female characters in the Anglo-American novel. His enthusiasm for literary history was such that he was known to send drafts of his essays 
to literary historians for fact-checking, and he personally urged playwright and critic Brander Matthews to write a literary history for schoolchildren, an endeavor that became Matthews' enormously successful textbook, An Introduction to the Study of American Literature (1896).

This shared enthusiasm for literary history was undercut by the widening chasm of aesthetics separating the two men, for their dissimilar sensibilities bred equally dissimilar ideas about what literary history could achieve and claim. Howells' role as promoter and codifier of realism hardly needs rehearsing, as he tirelessly advanced a literary aesthetic he characterized by the faithful, appreciative documentation of ordinary life, which he described as the "simple, the natural, and the honest." hand, was a known adherent of idealism, an aesthetic often constituted as realism's foil in late-century aesthetics. Idealism disputed the quotidian interests of realism and argued that, instead of reifying American life, literature should depict an idealized world that would refine and inspire it. Idealism likewise took exception to the realist focus on the minutiae of daily life and claimed that such a restricted concentration on empirical data was insufficient for a fully realistic portrait of life. Stedman instead encouraged supplementing such data with the use of imagination and intuition, for without them, he claimed, realist writings were merely "stiff, barren, and grotesque,- the form without the soul. They deal with the minor facts of

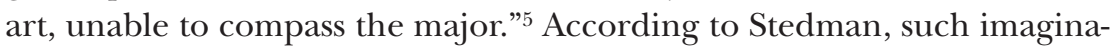
tive flights imbued a vitality to texts that could not be otherwise achieved through the mere recitation of data and empirical research. "True Realism," Stedman argued, "is just as faithful to the ideal and to the soul of things as to obvious and external matters." 6

Inherent in these competing aesthetics are profoundly different views of determinacy and the evidentiary value of data. For the idealist Stedman, empirical data was at best partial and merely hinted at philosophical or experiential truths lacking a material expression. The full truth, whether of the past or the present, was inaccessible by way of archival fact-gathering alone and remained permanently uncertain, even if supplemented by intuition and imagination, as Stedman recommended. On the other hand, such data occupies a central role in Howellsian realism and its efforts to document the authentic textures of everyday life. For Howells, material objects and physical details provide invaluable insight into a knowable world; inner lives in Howellsian realism do have a material expression, and one need only observe the contents of a parlor or the color of an evening gown to gain access to a person's interiority. ${ }^{7}$ These different views certainly produced widely divergent literary texts, but Stedman and Howells also brought them to bear on literary history. Stedman's willingness to step outside the bounds 
of data collection is visible throughout Poets of America, which is studded with moments of speculation and fancifulness. For example, in his chapter on William Cullen Bryant, Stedman used Bryant's patriotic poems as a point of departure for an imaginative flight of fancy: he wrote, "The country is the open wild of liberty. All our poets of nature are poets of human rights. Should America ever become monarchical it will be due to the influence of cities and those bred in them." passage are visible in its unconflicted imaginative conjecture and in its departure from the confines of verifiable data.

Howells flatly denounced these idealist traits in Stedman's volume to suggest that the book's imaginative departures from the terra firma of verifiable, researched data had made it error-ridden and too flaky to be considered a serious work of scholarship, an assessment underwritten by Howells' own realist sympathies. By way of proof, Howells spent most of his review exposing some of Stedman's more controversial assertions, among them his claim that Howells had abandoned poetry not for aesthetic reasons but for financial ones, anticipating that fiction would prove more "remunerative." ${ }^{9}$ Similarly, Howells took aim at Stedman's prediction of a poetry revival, a contention that Howells depicted as equally baseless in light of poetry's waning importance in contemporary literary culture; he remarked with sang-froid, "if we are at the end of our great poets for the present, we do not know that we shall altogether despair." ${ }^{10}$ In discrediting several of Stedman's facts, Howells demonstrates how intuitive supposition and the dismissal of factual corroboration had only compromised the book's integrity and factual reliability. But the vestige of Stedman's idealism that elicited Howells' most stringent commentary was his avid promotion of genius, a term Stedman used to describe over a half dozen American writers in Poets of America. Howells unflinchingly attacked one of idealism's core beliefs with his declaration that " $[\mathrm{t}]$ here is no 'genius'; there is only the mastery that comes to natural aptitude from the hardest study of any art or science."11 In the tense flurry of publications about genius that ensued, discussion returned repeatedly to the epistemological problem of determinacy and the merits of data that underlay their aesthetic rift. Their warring claims about the limits of knowledge replayed the idealist/realist rivalry so that, for Stedman, genius typified the idealist belief in the finitude of human knowledge whereas genius for Howells demonstrated the necessity of empiricist research rooted in verifiable facts.

Genius emerges in Stedman's writings less as the zenith of human achievement than as the ultimate literary historical mystery, the talent that defies contextualization and whose sources remain inexplicable. As with his remark in the essay "Genius" that the genius "knows without learning, and teaches the world what he has never learned," he constituted the genius as one whose 
works are recognized by their departure from contemporaneous practice and resistance to historicization. ${ }^{12}$ For example, in his discussion of Edgar Allan Poe in Poets of America, Stedman fails to find Poe's creative sources: Poe "was, after all, a man of like passions with ourselves. . . Thousands have gone as far toward both [temperamental] extremes, and the world has never heard of them." ${ }^{13}$ Without a logical explanation to turn to, Stedman throws up his hands at the literary historical enterprise and dubs him a genius: Poe, he wrote, "must have had genius to furnish the basis" for his work. ${ }^{14}$ Similarly, in his discussion of Whitman in Poets of America, Stedman suggests that traditional evaluative criteria are simply insufficient, for " $[\mathrm{t}]$ o judge him in conformity with these ideas lessens our estimate of his genius. Genius is greatly consistent when most audacious." ${ }^{15}$ Genius comes into view for Stedman with the failures of conventional sources of historical explanation such as archival fact-gathering. Thus genius both legitimizes the idealist belief in the limitations of empiricism and emerges as the ultimate practitioner of idealist methods. As Stedman remarked in the essay "Genius," composed in response to Howells, the genius can be recognized by his or her innate idealist tendencies: "it is the privilege of genius to see the soul of things; not merely their externals, but to know, to feel, the secret meaning of all that makes up life," an ability he termed an "ideal tendency." 16 As Stedman classified it, the genius is unbound by the precincts of materiality and is able to see past the commonplace to arrive at new but no less truthful ways of looking at the world.

Stedman's portrait of genius imported to the United States a debate that had already proved volatile among European literary historians. The origins of the Western belief in genius derive from antiquity, when, according to Penelope Murray, genius was understood as the divine entity or muse responsible for the production of poetry. ${ }^{17}$ The poet was extraordinary in part because of the readiness with which such divine influence could be discerned, and poetry in such a setting was construed as the visible product and evidence of divine intervention that, though believed to be widespread, was less noticeable elsewhere. The designation of the genius as someone able to heighten or illuminate the commonplace became institutionalized under Romanticism. ${ }^{18}$ Whereas antiquity regarded genius as evidence of divine involvement in human affairs, Romanticism stressed instead the "idea of man transcending himself": the ability of the artist's imagination to reach beyond immediate material circumstances and limitations to arrive at otherwise undetectable beauty, meaning, or sentiment amid the commonplace. ${ }^{19}$

This depiction of the genius as unconstrained by empirical limitations was quickly recognized as innately problematic to the enterprise of history. 
By the 1790 Immanuel Kant constituted genius in the Critique of Judgment as aptitude with unknown origins, which "no science can teach and that cannot be learned by any diligence." ${ }^{20}$ For some European critics of the nineteenth century, genius exposed a flaw in literary history, and detractors such as turn-of-the-century French critic Emile Faguet argued that "historical contextualism" could "explain everything except what, perhaps, one most wants to explain-'genius.' "21 In 1863 French critic Edmund Scherer wrote in a review of Hippolyte Taine's history of English literature that history has "been at all times conceived to be . . . a narrative. Its purpose is to make the actions of men known to inquirers into the causes of these actions, because that is a means of producing a better understanding of them. But its researches are limited to those causes which are a matter of documentary evidence. There history stops." "A man's genius," Scherer wrote, "is a fact which we are powerless to explain, which we must accept without attempting to determine its laws." ${ }^{22}$ As Drummond Bone puts it, genius is "a kind of aporia. It refers to ... [that] which escapes the very categories of comprehension and of speech." ${ }^{23}$ As such, the genius defies the mission of literary history of situating writers within historical context and within a chronology of achievement, for the ahistorical nature of such works of genius renders context an impotent source of explication. All of this led to the suggestion that empiricist methods and fact-finding might be leading literary history to a dead end, for they apparently couldn't deliver the ne plus ultra of literary historical scholarship: the sources of literary achievement and inspiration.

This historiographical debate never took hold in American literary historical discourse the way it had in Europe because Howells effectively sandbagged it by intimating in his 1886 review that no serious modern person could believe in such a thing. Howells countered the attributions of genius in Poets of America with an alternate interpretation of the inexplicability of genius; rather than signaling the failure of literary history, as these other critics had suggested, its defiance of positivist research technique evidences instead its nonexistence. If it can't be tracked, explained, and analyzed, then it can't definitively be said to exist at all. Howells asked with incredulity, "do [the defenders of genius] really believe it? Can they severally lay their hands upon their waistcoats and swear that they think there is any such thing?" ${ }^{44}$ He emphasized this point to suggest that a "superstition" devoid of factual corroboration other than the fervent guarantees of a few idealists is no foundation on which to build a work of literary historical scholarship. ${ }^{25}$ After all, we don't expect geographers or oceanographers to attribute natural and scientific phenomena to such marvels as the Maelstrom because " $[\mathrm{t}]$ here is no Maelstrom sucking down ships and vomiting up bottles with 
MSS. in them; there is only a bad current off the coast of Norway." 26 That is, we expect scientific works of scholarship to draw rational explanations from verifiable data, and, in comparing genius to the Maelstrom, Howells implies that we should no expect no less from works of literary scholarship. He here pits idealist imaginative fancy against the unsentimentality of realist fact-gathering to suggest that literary history is no place for the idealist aesthetic, which, as he characterizes it, privileges the aesthetically pleasing over the factually accurate and threatens to transform literary history into a repository for fantasy, rumor, and unsubstantiated theory. In a cutting aside on the damaging effects of idealism on literary history, Howells asked, "What won't a man sacrifice to a theory, especially a wrong one?"27

Howells' review argues that "great men"-Stedman's geniuses-are no less the products of observable historical circumstance than the rest of us, and Howells directly challenged idealist epistemology by offering a vision of a world made intelligible through realist methods. One need only be sensible and observant enough to discern the meaningful details that explain one's character and work. He remarked,

as we come to know great men better, we come to see that, after all, they are of one blood with the well-known human race, and no miracles of creation. They seem each thoroughly of his time and place, and this or that tendency of civilization appears to have found its most striking expression in them. Napoleon was the creature of the French Revolution, as Grant was the creature of our civil war. ${ }^{28}$

"Great men" are rooted in the specifics of their time periods, and Howells insists that it is the responsibility of the historian to relay the circumstances of their development and achievement, a task that he models with a discussion of Ulysses S. Grant's recently published Memoir. "All the conditions [of Grant's life] are favorable to supposing a case of 'genius,'” Howells wrote, and yet he systematically debunks this claim by relating some of the more verifiable contexts of the general's achievements that belie such an attribution: West Point, his father's encouragement, his patriotism, as well as a "plain, taciturn, simple, unaffected soul." ${ }^{29}$ Achievement, Howells aims to show, can be regarded in context, and so critics therefore ought to limit themselves to the discussion of certainties, such as the material and historical contexts by which such men were able to cultivate their "natural aptitude" through "the hardest study." ${ }^{30}$ Ultimately, Howells' review argued that acceptable literary history was discernible by its adherence to the realist worldview and that the belief in genius was at best the misguided fancy of idealistic dreamers and at worst a scholarly short-cut in the place of painstaking research into a writer's life. 
In putting Stedman on the defensive, Howells made him the apologist for these enduring historiographical questions, and Stedman championed his cause as best he could, responding several months later with the publication of the lengthy essay "Genius" in the New Princeton Review. Stedman faced a serious problem in defending his beleaguered positions, for how can one credibly use such argumentative, logical tools as facts, material history, and context to argue against their use? It is a truism that the master's tools will never dismantle the master's house, but Stedman certainly tried to use the empiricist tools and techniques he critiqued to defend his belief in genius as the unreachable frontier of historical exegesis. His retort is composed chiefly of excerpts and corroborating opinions from major thinkers across Western history-among them the Platonists, Dryden, Carlyle, and James Russell Lowell-endorsing the existence of supra-mortal abilities that defy explanation or reason. In this way, Stedman paradoxically relied almost exclusively on historical evidence and precedent to justify his belief in the limits of historical knowledge. Indeed, in his review, Howells had made the obverse move, rejecting historical convention as insufficient explanation for rejecting historical knowledge; that people had always believed such a thing didn't justify continuing to believe in such questionable phenomena as the Maelstrom or genius.

That Stedman turned toward history to defend his belief in the limits of historical knowledge is evident in the Library of American Literature ( $1888-$ 9o), the eleven-volume anthology Stedman co-edited with Ellen Mackay Hutchinson. Spanning American literature from 1607 through 1888, the Library plays a central role in the history of American literary study and of the discipline of American literary history; though seldom cited today and largely unknown even by specialists of late-century American literature, it was nonetheless the nation's first far-reaching anthology of American literature, widely consulted and cited by generations of American literary scholars and historians well into the mid-twentieth century. By the time of Howells' review in 1886 , Stedman has already begun work on the Library, and it is clear that Stedman used the anthology to respond to Howells' review by anthologizing excerpts from texts that also corroborated a belief in genius and the limits of material, historical knowledge. The contents of this massive anthology warrant their own considered analysis, but even a cursory glance at the tables of contents (all eleven of them) reveal that the editors had paid clear homage to their loyalties and professional allegiances. For example, the anthology paid particular attention to Hutchinson's place of employment, the New York Tribune, and anthologized the work of many of her colleagues, among them Isaac Hill Bromley, George Washington Smalley, William Winter, and Whitelaw Reid. 
The fingerprint of Stedman's scrap with Howells is apparent in the wealth of reprinted excerpts from numerous texts designed to defend Stedman's belief in genius and the limits of historical knowledge. Volume nine of the anthology, for example, included the work of Junius Henri Browne, a writer for the Tribune. A well-regarded critic and journalist, Browne was best known for his memoir Four Years in Secessia (1865), which recounted his experiences as a correspondent during the Civil War, his capture at Vicksburg, lengthy imprisonment in a Confederate prison, and escape northward. However, the editors chose not to reprint an excerpt from this memoir of national importance and instead anthologized an obscure 1878 essay entitled "Genius and Labor" originally published in Appleton's Journal. Though of minimal wider significance, the essay both lent support to Stedman's embattled position on genius and neatly addressed many of the objections raised by Howells. It directly countered, for example, Howells' contention that literary genius downplayed authorial labor, for Stedman edited the excerpt to begin with the observation that " $[\mathrm{t}]$ here are two distinctive kinds of genius, although there is but one kind of labor. There is the genius which is patient, toilsome, persevering, which accomplishes something, which becomes known. There is also the genius which is careless [and] indolent." 31

Other examples abound in the literary history. Volume seven included an excerpt from Rufus Griswold's infamous biography of Poe, though the editors tailored the selection both to make a case for the literary value of Poe, who was often dismissed by late-century critics who found his personal life repellant, and to substantiate Stedman's stance on genius, for their selection reprinted only Griswold's discussion of Poe's "supramortal” abilities, his channeling of the divine and otherworldly into his work. ${ }^{32}$ The editors took some liberty in titling this excerpted selection "The Genius and Character of Poe," a maneuver designed to validate Stedman's belief that true literary greatness required freedom from the constraints of daily life and imaginative communion with otherworldly powers. Similarly, volume seven anthologized the work of Rabbi Isaac Mayer Wise, one of the founders of American Reform Judaism. One might expect the anthology to anthologize perhaps some of Wise's more important theological writings or excerpts from the Union Prayer Book of the Reform movement. But they instead excerpted selections from his book The Cosmic God (1876), which they titled "An Hebraic View of Genius." The selection is obviously edited to lend religious weight to the concept of genius and uses the imprimatur of the Hebrew Bible to legitimize Stedman's recorded position: "The existence of genius and its appearance at the right place and time is as mysterious as the centre of the universe. Genius is the superior spontaneity of the mind in productive and executive powers. It conceives, not by an act of volition or 
tiresome reflection, but freely, generously, and unsolicited. . . . The ancient Hebrews called it Ruach hak-kodesh, a 'holy spirit,' and modern language names it Genius."33

Similarly, the Library directly challenged Howells' dismissive remarks about poetry. The final three volumes of the anthology, which cover the years between 1861 and 1888 , are positively overwhelmed by American poetry, with literally hundreds upon hundreds of pages allotted to verse. The density of poetry, as well as the widely varying quality of excerpted poetry, suggests that the editors had simply combed the pages of magazines and periodicals from those decades to find examples of poetry in a clear effort to affirm the continuing viability and prosperity of American poetry. The impetus to demonstrate the enduring vitality of poetry was so great that the editors made a series of noteworthy decisions, such as their inclusion of African American spirituals and songs, selections that, splayed out on the inert printed page, evidence thriving home-spun folk poetry. Volume eleven similarly included a section of thirty pages entitled "Various Poems," which reprinted single poems by such figures as abolitionist William Lloyd Garrison and journalist Charles Henry Crandall, plus a few anonymously written poems. The editors even anthologized the verse of their lawyer, Charles Henry Phelps. And in an especially strong gesture, the anthology reprinted several poems by Howells himself as a reminder of his earlier generic loyalties and aspirations.

Likewise, in a gesture of aesthetic revenge, these volumes significantly downplayed realist fiction of the post-war period. For instance, the first two hundred pages of volume ten, which covers the 1870 os and 8os, anthologized fifty-five writers. Out of those fifty-five writers, only five were writers of realist fiction whose excerpts included realist texts. ${ }^{34}$ The remainder of these first two hundred pages of the volume is composed of a combination of poetry and non-fiction: varied historical writings, political and economic writings, literary criticism, and philosophy. Moreover, the selections devoted to these five fiction writers were designed to downplay their fiction and to showcase their contributions to other genres: for example, the pages devoted to Henry James emphasized his non-fiction writings, and the pages devoted to both Bret Harte and George Alfred Townsend reprinted some of their poems, an inclusion that pointedly demonstrates that the rising popularity of fiction need not necessarily entail the demise of poetry.

Despite Stedman's efforts to make a compelling case for his aesthetic and generic loyalties, there is no doubt that Howells' opinion carried the day. While Stedman had the media of literary history and anthologies on his side, Howells had the more powerful venue of his Harper's columns. Though a few idealist critics such as Columbia professor George Edward 
Woodberry sided with Stedman and incorporated idealist aesthetics into their works of literary history, the vast majority of turn-of-the-century literary historians employed methods that affirmed the powers of historical knowledge and corroborated Howells' empiricist beliefs. While the proliferation of Howells' methods in the short-term may be due in part to the minor publicity sensation caused by this quarrel and the damaging public consequences of diverging from his opinions about the methods and mission of American literary history, Howells' lasting victory may also be due to the fact that he more effectively controlled the discourse, framing the issue with rhetoric that made his positions irresistible. Defining genius as the hallmark of inborn greatness, Howells characterized it as essentially un-American and undemocratic. Genius, Howells remarked, is "a doctrine wholly opposed to the spirit of free institutions and the principles of civil service reform." 35 Howells interpreted genius as a signifier of aristocratic sympathy both because of its apparent celebration of innate superiority and because of its seeming incongruity with the late-century spirit of literary self-fashioning that had enabled so many writers of lowly pedigree and little formal education-such as Hamlin Garland, Mark Twain, and Howells himself-to assume places of national prominence. This interpretation was fortified by Stedman's depiction of authorship as a purely passive activity made possible by inborn gifts, a characterization that freely accessed lingering American perceptions of authorship as an indolent, leisured avocation of a privileged few and one that Howells attempted to dismantle throughout his life by depicting writing as arduous labor.

The self-educated and class-conscious son of an erratically-employed lowermiddle-class printer, Howells remained sensitive throughout his life to the whiff of such literary aristocratic sensibilities, whether in the American belief in authorship as an aristocratic prerogative or in the patrician pretensions of fellow writers. ${ }^{36}$ Howellsian realism may certainly be understood as an aesthetic expression of this lifelong class sensitivity, as with his repeated calls for American writers to cease peddling literary fantasies of the aristocracy modeled after Walter Scott's Waverley novels and adopt instead common, plebian life as their source of literary inspiration. Howells' realist aesthetic aimed to overturn literary class hierarchies by replacing literary fantasies about the already-powerful with celebrations of the commonplace and lowly. Howells responded as violently as he did to Stedman's literary history in part because it hinted of an attempt to topple this democratic sensibility and restore authorship to the prerogative of a leisured few. In liberally bestowing literary laurels of the most grandiose and daunting kind, Stedman seemed to constitute the American literary past so as, by contrast, to diminish the literary present and to foreclose a literary future peopled by a more economically 
and geographically diverse population. As dramatized in Howells' fantasy of "trembling" "poor little authorlings . . in question of whether they have [genius], or have only "talent," the elevation of some writers above human heights, according to Howells, promised to make literary achievement seem even more supernal and unattainable than usual and therefore to remove it altogether from the reach of the literally poor. ${ }^{37}$

And so Howells took pains in his review to reinstate his own classed vision of authorship as a demanding form of labor available to anyone with some skill and a strong work ethic, and to level the literary playing field by constituting success as chiefly dependent upon the writer's own toil. In the place of genius, he wrote, "there is only the mastery that comes to natural aptitude from the hardest study of any art or science." 38 In this way, Howells attempted to rewrite the American literary past from Stedman's intimidating, idealized pantheon of inborn greatness to a more realism-informed paradigm of self-determination and diligence that he thereby channeled into a vision of an equally labor-intensive method of literary history. With the debate formulated thus, American literary historians had no choice but to reject idealist methods that had been summarized so convincingly as aristocratic in nature and to adopt instead empiricist methods that announced themselves as based in such middle-class values as self-reliance and industry.

Characterized in this fashion by Howells and left to languish as a fringe literary historical methodology that failed to catch on, Stedman's idealist practices are nonetheless important in a historiography of the field, for it once entertained practices that freely acknowledged the limitations of realist research methods and embraced the imagination as a legitimate source of scholarly inquiry. The recent rise of a generation of scholars willing to question the methods Howells endorsed suggests that the disciplinary pendulum swing may finally be moving toward greater sympathy to Stedman's ideas. Numerous important literary historians and editors of major national literary histories-among them R. Howard Bloch, Emory Elliott, Denis Hollier, Linda Hutcheon, David Perkins, and David Wellbery-have examined how realist literary history can fall prey to overweening certainty, the illusion of critical consensus, and historical incompleteness. This last consequence is due to the expectation that the literary historian "suppress whatever perceptions do not fit with his plot construction," a requirement that may lead, as it had with Howells in 1886, to the excision of unresolved debates and questions. ${ }^{39}$ In his preface to the Columbia Literary History of the United States (1988), Elliott explained his skepticism about the historical concreteness demanded by Howells and disdained by Stedman, thereby voicing some of the chief complaints about this realist form: 
This work [the Columbia Literary History of the United States] does not . . constitute a new consensus about the history of the literature of the United States. For many reasons ... concurrence remains impossible at this time. There is today no unifying vision of a national identity like that shared by many scholars at the closing of the two world wars. We have therefore sought to represent the variety of viewpoints that enliven current scholarship [with] . . individual essays. ${ }^{40}$

Linda Hutcheon raised similar objections in her complaint that "the earlier model of literary history stubbornly persists, not so much in the form of a simple explanatory or causal narrative (though it too continues), but, more obviously, in a teleological narrative of continual and organic evolution." ${ }^{4}$ For both Elliott and Hutcheon, the insistence on causal explanation and narrative coherence in literary history only compromises the scholarly integrity it seeks to fortify. Recent monumental works of literary history as the New History of French Literature (1989) and New History of German Literature (2004) employ a wide range of experimental forms and techniques designed to evade the unifying certainty and explanatory diachrony mandated by realist literary historical technique. In addition, recent works of literary biography—such as Andrew Delbanco's Melville: His World and Work (2005) and Colm Tóibín's The Master (2004) — freely draw on the literary imagination critiqued by Howells and endorsed by Stedman, a gesture that challenges the realist emphasis on empirical data. As suggested by all these recent developments, literary history may finally be sympathetic to some of the positions Stedman fervently espoused.

- Trinity University

\section{Notes}

I wish to thank Michael Fischer and Robert Scholnick for their considerable help with this essay. I would also like to thank the William Dean Howells Society for its warm, helpful response to an earlier version of this essay I presented at the 2005 meeting of the American Literature Association.

1. W. D. Howells, "Editor's Study," Harper's Monthly, 72 (March 1886), 647.

2. Stedman wrote a lecture on genius that he delivered in 1891 at the Johns Hopkins University and that he later included in the volume The Nature and Elements of Poetry (1892). The quarrel between Stedman and Howells did not end with Stedman's death in 1908. Three years later his granddaughter Laura Stedman and George M. Gould coedited a collection of his essays that opened with his eponymous response to Howells. See Genius and Other Essays (New York: Moffat, Yard, 1911 ).

3. For further information about the formation of this field in the turn of the last century, see my book Writers in Retrospect: The Rise of American Literary History, I875-19IO (Chapel Hill: Univ. of North Carolina Press, 2006).

4. Howells, "Criticism and Fiction," in Selected Literary Criticism, ed. Christoph K. Lohmann and Donald Pizer (Bloomington: Indiana Univ. Press, 1993), II, 301. 
5. Stedman, Victorian Poets (1875; rpt. Boston: Houghton Mifflin, 1893), p. 359 .

6. Stedman, Victorian Poets, p. 479.

7. Bill Brown has offered invaluable commentary on the role of material objects in this literary period. See his A Sense of Things: The Object Matter of American Literature (Chicago: Univ. of Chicago Press, 2003).

8. Stedman, Poets of America (1885; rpt. Boston: Houghton Mifflin, 1913), pp. 91-92.

9. Stedman, Poets of America, p. 462. This financial claim was by no means an out-ofcharacter assessment from Stedman, who could barely make ends meets as a stock broker and openly regarded his own literary work as his chief means of financial support. His ugly correspondence with publishers and lawyers over royalties for the Library of American Literature evidences that Stedman himself made career decisions less on the basis of aesthetic philosophy and interest than out of dire financial need, and he seems here to perceive in Howells his own biases and methods.

10. Howells, "Editor's Study," p. 647.

11. Howells, "Editor's Study," p. 65 o.

12. Stedman, Genius and Other Essays, p. 24.

13. Stedman, Poets of America, p. 226.

14. Stedman, Poets of America, p. 227.

15. Stedman, Poets of America, pp. 367-68.

16. Stedman, Genius and Other Essays, pp. 27-28.

17. Penelope Murray, "Poetic Genius and Its Classical Origins," in Genius: The History of an Idea, ed. Murray (London: Basil Blackwell, 1989), pp. 10-1 1. Stedman's persistent exaltation of poetry as a sacred form clearly derived from this early Greek definition of genius, as did his conviction that truly great poetry derived not from immediate material circumstance, as Howells claimed, but from an otherworldly source he termed "The Faculty Divine." See his The Nature and Elements of Poetry (Boston: Houghton Mifflin, $1892)$, p. 259.

18. Jonathan Bate, "Shakespeare and Original Genius," in Genius: The History of An Idea, p. 76; and Drummond Bone, "The Emptiness of Genius: Aspects of Romanticism," in Genius: The History of An Idea, pp.113-14.

19. Benjamin Taylor, Into the Open: Reflections on Genius and Modernity (New York: New York Univ. Press, 1995), p. 2.

20. Immanuel Kant, Critique of Judgment, trans. Werner S. Pluhar (Indianapolis: Hackett, $1987)$, p. 185 .

21. Quoted in David Perkins, Is Literary History Possible? (Baltimore: Johns Hopkins Univ. Press, 1992), p. 7.

22. Edmond Scherer, Essays on English Literature, trans. George Saintsbury (1891; Freeport: Books for Libraries Series, 1972), pp. 73, 76 .

23. Bone, p. 113.

24. Howells, "Editor's Study," p. 649.

25. Howells, "Editor's Study," p. 649.

26. Howells, "Editor's Study," p. 65 o.

27. Howells, "Editor's Study," p. 648.

28. Howells, "Editor's Study," p. 65 o.

29. Howells, "Editor's Study," p. 649.

3o. Howells, "Editor's Study," p. $65^{\circ}$.

31. Junius Henri Browne, "Genius and Labor," in Library of American Literature, ed. Edmund C. Stedman and Ellen Mackay Hutchinson (New York: William Evarts Benjamin, 1894), IX, 116.

32. Rufus Wilmot Griswold, "The Genius and Character of Poe," in Library of American Literature, VII, 286.

33. Isaac Mayer Wise, "An Hebraic View of Genius," in Library of American Literature, VII, 402 . 
34. These writers are George Cary Eggleston, Bret Harte, Henry James, Charles Bertrand Lewis, and George Alfred Townsend.

35. Howells, "Editor's Study," p. $65^{\text {o. }}$

36. Susan Goodman and Carl Dawson, William Dean Howells: A Writer's Life (Berkeley: Univ. of California, 2005), pp. 10-18.

37. Howells, "Editor's Study," p. 649.

38. Howells, "Editor's Study," p. 65 o.

39. Perkins, p. 20.

4o. Emory Elliott, "Preface" to The Columbia Literary History of the United States, ed. Elliott et al. (New York: Columbia Univ. Press, 1988), pp. xi-xii.

41. Linda Hutcheon, "Interventionist Literary Histories: Nostalgic, Pragmatic, or Utopian?," Modern Language Quarterly, 59 (December 1988), 404. 